\title{
The CO poisoning effect in PEMFCs operational at temperatures up to 200 degrees C
}

\author{
Li, Qingfeng; He, Ronghuan; Gao, Ji-An; Jensen, Jens Oluf; Bjerrum, Niels
}

Published in:

Journal of The Electrochemical Society

Link to article, DOI:

$10.1149 / 1.1619984$

Publication date:

2003

Document Version

Publisher's PDF, also known as Version of record

Link back to DTU Orbit

Citation (APA):

$\mathrm{Li}$, Q., He, R., Gao, J-A., Jensen, J. O., \& Bjerrum, N. (2003). The CO poisoning effect in PEMFCs operational at temperatures up to 200 degrees C. Journal of The Electrochemical Society, 150(12), A1599-A1605.

https://doi.org/10.1149/1.1619984

\section{General rights}

Copyright and moral rights for the publications made accessible in the public portal are retained by the authors and/or other copyright owners and it is a condition of accessing publications that users recognise and abide by the legal requirements associated with these rights.

- Users may download and print one copy of any publication from the public portal for the purpose of private study or research.

- You may not further distribute the material or use it for any profit-making activity or commercial gain

- You may freely distribute the URL identifying the publication in the public portal

If you believe that this document breaches copyright please contact us providing details, and we will remove access to the work immediately and investigate your claim. 
Journal of The Electrochemical Society, 150 (12) A1599-A1605 (2003)

A1599

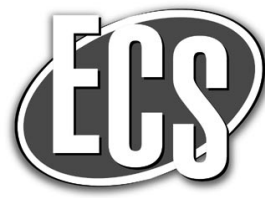

0013-4651/2003/150(12)/A1599/7/\$7.00 @ The Electrochemical Society, Inc.

\title{
The CO Poisoning Effect in PEMFCs Operational
} at Temperatures up to $200^{\circ} \mathrm{C}$

\author{
Qingfeng Li, ${ }^{*, z}$ Ronghuan He, Ji-An Gao, Jens Oluf Jensen, \\ and Niels. J. Bjerrum*
}

Materials Science Group, Department of Chemistry, Technical University of Denmark, DK-2800 Lyngby, Denmark

\begin{abstract}
The $\mathrm{CO}$ poisoning effect on carbon-supported platinum catalysts (at a loading of $0.5 \mathrm{mg} \mathrm{Pt} / \mathrm{cm}^{2}$ per electrode) in polymer electrolyte membrane fuel cells (PEMFCs) has been investigated in a temperature range from 125 to $200^{\circ} \mathrm{C}$ with the phosphoric acid-doped polybenzimidazole membranes as electrolyte. The effect is very temperature-dependent and can be sufficiently suppressed at elevated temperature. By defining the CO tolerance as a voltage loss less than $10 \mathrm{mV}$, it is evaluated that $3 \% \mathrm{CO}$ in hydrogen can be tolerated at current densities up to $0.8 \mathrm{~A} / \mathrm{cm}^{2}$ at $200^{\circ} \mathrm{C}$, while at $125^{\circ} \mathrm{C} 0.1 \% \mathrm{CO}$ in hydrogen can be tolerated at current densities lower than $0.3 \mathrm{~A} / \mathrm{cm}^{2}$. For comparison, the tolerance is only $0.0025 \% \mathrm{CO}(25 \mathrm{ppm})$ at $80^{\circ} \mathrm{C}$ at current densities up to $0.2 \mathrm{~A} / \mathrm{cm}^{2}$. The relative anode activity for hydrogen oxidation was calculated as a function of the CO concentration and temperature. The effect of $\mathrm{CO}_{2}$ in hydrogen was also studied. At $175^{\circ} \mathrm{C}, 25 \% \mathrm{CO}_{2}$ in the fuel stream showed only the dilution effect.

(C) 2003 The Electrochemical Society. [DOI: 10.1149/1.1619984] All rights reserved.
\end{abstract}

Manuscript submitted January 17, 2003; revised manuscript May 23, 2003. Available electronically November $12,2003$.

Polymer electrolyte membrane fuel cells (PEMFCs) generally perform best on pure hydrogen, but for many applications, especially mobile, pure hydrogen is not yet a viable option due to lack of availability and impractical storage techniques. Meanwhile, on-site generation of hydrogen by steam reforming of various organic fuels (methanol, natural gas, gasoline, etc.) is an obvious choice. The reformate gases contain, besides hydrogen and carbon dioxide, a small amount of carbon monoxide (CO). Conventional PEMFCs operate around $80^{\circ} \mathrm{C}$. At this temperature a $\mathrm{CO}$ content as low as $10-20 \mathrm{ppm}$ in the fuel feed results in a significant loss in cell performance due to $\mathrm{CO}$ poisoning of the electrode catalyst. ${ }^{1}$ Therefore a strict purification of the reformate gas is necessary in order to remove $\mathrm{CO}$ down to a $10 \mathrm{ppm}$ level. This is carried out by means of the water-gas shift reaction, preferential oxidation, membrane separation, or methanation. The main challenge for a PEMFC system, especially as a small dynamic power source for vehicles, is the complexity of the fuel processing system. Such a system currently covers $40-50 \%$ of the total system cost and considerably increases the system size, volume, weight, and time for start-up and transient response. A CO-tolerant PEMFC technology would decisively simplify the fuel cell system.

Oxidation of hydrogen on the anodic platinum catalyst is known to take place in two steps, i.e., dissociative chemisorption and electrochemical oxidation. The dissociative chemisorption of a hydrogen molecule requires two free adjacent sites of the platinum surface atoms

$$
\begin{array}{r}
\mathrm{H} \mathrm{H} \\
\mathrm{H}_{2}+\mathrm{PtPt} \leftrightarrow \mathrm{PtPt}
\end{array}
$$

The electrochemical oxidation of the chemically absorbed hydrogen atoms produces two free platinum sites, two hydrogen ions, and two electrons

$$
\begin{aligned}
& \text { H H } \\
& \text { | } \\
& \mathrm{PtPt} \leftrightarrow \mathrm{PtPt}+2 \mathrm{H}^{+}+2 \mathrm{e}^{-}
\end{aligned}
$$

In case of the pure hydrogen oxidation, both step 1 and step 2 are very fast, corresponding to a very large exchange current density. ${ }^{2}$ In a PEMFC, the hydrogen anode exhibits an overpotential of less than $100 \mathrm{mV}$ under operational conditions.

When the hydrogen gas stream contains carbon monoxide $(\mathrm{CO})$, $\mathrm{CO}$ competes with hydrogen for the adsorption sites of platinum

$$
\begin{aligned}
& \text { O } \\
& \text { III } \\
& \text { C } \\
& \text { I } \\
& \mathrm{CO}+\mathrm{Pt} \leftrightarrow \mathrm{Pt} \text { (linearly bonded) } \\
& \begin{array}{c}
\mathrm{O} \\
\| \\
\mathrm{C} \\
\wedge \\
\mathrm{CO}+\mathrm{PtPt} \leftrightarrow \mathrm{PtPt} \quad \text { (bridge-bonded) }
\end{array}
\end{aligned}
$$

Two types of bonding modes of the adsorbed $\mathrm{CO}$ molecules have been suggested, as shown in Reaction 3. The linearly absorbed carbon monoxide species involves one adsorption site per $\mathrm{CO}$ molecule, while the bridge-bonded $\mathrm{CO}$ species requires two adjacent platinum surface sites. ${ }^{3,4}$ The sorption equilibrium is strongly in favor of adsorption and desorption takes place most easily via oxidation of $\mathrm{CO}$ to $\mathrm{CO}_{2}$. The oxygen atoms necessary for the reaction are then obtained from the dissociation of the humidification water or the water present in the proton exchange membranes

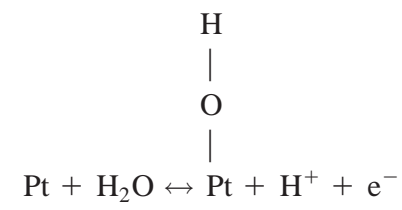

in order to oxidize the adsorbed $\mathrm{CO}$ to $\mathrm{CO}_{2}$ electrochemically

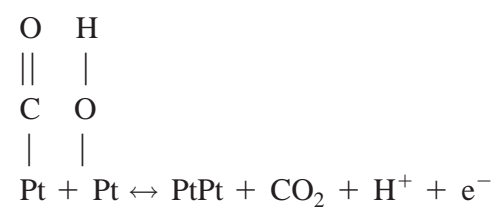




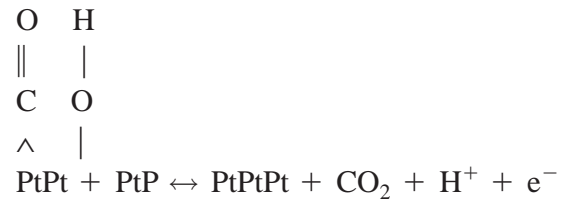

The rate-determining step for sequence $4-5$ is formation of the oxygen-containing adsorbate, Reaction 4. Based on these chemical and electrochemical surface processes a kinetic model has been developed. ${ }^{5}$ At low current densities or low anodic overpotentials, the anodic oxidation of hydrogen is essentially determined by the maximum rate of hydrogen dissociative chemisorption on a small fraction of the catalyst surface area free of $\mathrm{CO}$. This limiting current density is a function of the $\mathrm{CO}$ content in hydrogen and the operational temperature. When this limiting current density is exceeded, a much larger increase of the anode overpotential is observed due to the limited number of $\mathrm{CO}$-free $\mathrm{Pt}$ surface sites. The electrooxidation of the adsorbed $\mathrm{CO}$ occurs at the potential where the oxygen-containing species are formed at the platinum surface, i.e., corresponding to an anode potential around $0.5 \mathrm{~V}$ vs. RHE. Under operational conditions for a PEMFC, where the anode operates in a potential region between 0 and $0.1 \mathrm{~V} v s$. RHE, CO is hence an inert adsorbate on the platinum catalyst surface.

Considerable efforts have been made to develop CO-tolerant electrocatalysts. Niedrach et al. seem to be the first, who found that addition of $\mathrm{Ru}, \mathrm{Rh}$, and Ir into Pt could improve the CO-tolerance. ${ }^{6,7}$ Thereafter various alloys were investigated such as Pt-Sn, ${ }^{8}-10$ Pt-Mo, ${ }^{11-13} \mathrm{Pt}(\mathrm{Ru})-\mathrm{WO}_{3},{ }^{14,15}$ and others. ${ }^{16}$ Apparently Pt-Ru alloys are among the most promising candidates and have attracted more attention recently. ${ }^{17-20}$ It is proposed that the presence of $\mathrm{Ru}$ atoms in the alloys leads to a promoter effect for the oxidation of $\mathrm{CO}$ adsorbates according to a bifunctional mechanism, i.e., through the promotion of water dissociation and then $\mathrm{CO}$ oxidation. The potential for water dissociation and adsorption on $\mathrm{Ru}$ is lower than that on Pt (Reaction 4). ${ }^{21}$

Alternative approaches such as air-bleeding ${ }^{22}$ to the COcontaining anode feed stream or addition of hydrogen peroxide ${ }^{23,24}$ into an anode humidifier have been suggested. Even though the selectivity of the bleed oxygen is poor, i.e., the bleed oxygen reacts chemically with $\mathrm{CO}$ and consumes hydrogen as well, it has been shown that the voltaic improvements are much greater than the coulombic losses due to the hydrogen consumption. The mechanism of the $\mathrm{H}_{2} \mathrm{O}_{2}$ addition was originally suggested as the vapor transport of the $\mathrm{H}_{2} \mathrm{O}_{2}$ from the anode humidifier to the anode where the oxygen atoms were formed by dissociative chemisorption on the anode catalysts. ${ }^{23,24}$ However, Bellows et al. ${ }^{25}$ have demonstrated that $\mathrm{H}_{2} \mathrm{O}_{2}$ decomposes at the metallic surface of the anode humidifier and the real mechanism is also by the oxygen bleed effect.

It is well known that the adsorption of $\mathrm{CO}$ on platinum exhibits a high negative value for the standard entropy, indicating that the adsorption is strongly favored at low temperatures. ${ }^{26-28}$ At $130^{\circ} \mathrm{C}$, for example, platinum-based catalysts can tolerate up to $1000 \mathrm{ppm}$ $\mathrm{CO}$, compared to only $10 \mathrm{ppm}$ at $80^{\circ} \mathrm{C}^{29}$ Recently temperatureresistant polymer membranes, e.g., the acid-doped polybenzimidazole (PBI) membranes have been developed for operation at temperatures up to $200^{\circ} \mathrm{C} .{ }^{30,31}$ As rationalized by Wainright et al. ${ }^{30}$ and demonstrated by Savadogo et al. ${ }^{32}$ and our group, ${ }^{31}$ the high operational temperature makes it possible to improve the $\mathrm{CO}$ tolerance of PEMFCs. The present work examines the CO poisoning effect on the PEMFC performance based on the acid-doped PBI electrolytes at temperatures up to $200^{\circ} \mathrm{C}$.

\section{Experimental}

The used PBI was synthesized from the polymerization of 3,3'-diaminobenzidine tetrahydrochloride (Aldrich) and isophthalic acid (Aldrich) in polyphosphoric acid at $170-200^{\circ} \mathrm{C} .^{33}$ The PBI powder obtained was then dissolved in $N, N$-dimethylacetamide (DMAc) at $150^{\circ} \mathrm{C}$ under stirring. Membranes were cast using Petri dishes.
The major part of the solvent was evaporated in a ventilated oven in a temperature range from 60 to $120^{\circ} \mathrm{C}$. The membranes were then washed with distilled water at $80^{\circ} \mathrm{C}$ in order to remove the stabilizer and solvent. Traces of the solvent, DMAc, were removed by drying at $190^{\circ} \mathrm{C}$. The acid-doping was carried out by immersing the membranes in phosphoric acid at room temperature for at least 1 week. The membrane of thickness about $65 \mu \mathrm{m}$ was doped with $5.3 \mathrm{~mol}$ $\mathrm{H}_{3} \mathrm{PO}_{4}$ per repeating unit of PBI.

Both anodes and cathodes were prepared from carbon-supported platinum catalysts. The catalysts $(20 \mathrm{wt} \% \mathrm{Pt})$ supported on carbon black (Vulcan XC-72R, Cabot) were prepared by chemical reduction of chloroplatinic acid $\left(\mathrm{H}_{2} \mathrm{PtCl}_{6}\right)$. As the gas diffusion support, carbon paper (Toray TGP-H-120) was first wet-proofed by using $15 \%$ poly(tetrafluoroethylene) (PTFE) dispersion. Onto the wet-proofed carbon paper was a thin layer of PTFE-bonded (40\% PTFE) carbon powder applied as the supporting layer. A slurry of $\mathrm{Pt} / \mathrm{C}$ powder in $5 \%$ PBI solution in DMAc was then cast on top of the supporting layer and then dried at $190^{\circ} \mathrm{C}$ for a few hours. The loading of the noble metal was around $0.5 \mathrm{mg} / \mathrm{cm}^{2}$. The loading of the polymer in the catalyst layer was controlled in a range from 0.6 to $0.8 \mathrm{mg} / \mathrm{cm}^{2}$. The electrodes were then doped with $10 \%$ phosphoric acid. Assemblies from the acid-doped electrodes and polymer membranes were made by hot-pressing at $150^{\circ} \mathrm{C}$ for $10 \mathrm{~min}$.

A single test cell $\left(10 \mathrm{~cm}^{2}\right)$ was made of graphite plates with gas channels. Two aluminum end plates with attached heaters were used to clamp the graphite plates. Fuel and oxidant gases were supplied via mass flow controllers. Mixed gases were prepared in-line by mixing the individual gases using Bronkhorst (HI-TEC E-5514) controllers. Anode and cathode gasses were in all cases supplied under atmospheric pressure (plus the minor pressure drop in the cell). The gas flow rate was $27 \mathrm{~cm}^{3} / \mathrm{min}$ per $\mathrm{cm}^{2}$ of electrode working area, for both hydrogen (or its mixtures) and oxygen. The studied CO contents at different temperatures were from 0.1 to 16 vol $\%$ in the temperature range $125-200^{\circ} \mathrm{C}$. Chronoamperometry for the $\mathrm{CO}$ poisoning and recovering was recorded at a cell voltage of $0.5 \mathrm{~V}$ with a recording time interval of $0.01 \mathrm{~s}$. Chronoamperometric measurements showed that a steady state of the $\mathrm{CO}$ poisoning after the gas switch from pure hydrogen to hydrogen containing $\mathrm{CO}$ was reached after, e.g., about $30 \mathrm{~min}$ at $200^{\circ} \mathrm{C}$ but more than $2 \mathrm{~h}$ at $125^{\circ} \mathrm{C}$. Polarization curves were obtained by a current step potentiometry after a steady state of the poisoning was reached. Each polarization curve was measured beginning with the highest currents. Each current step lasted for 2 min.

\section{Results and Discussion}

Temperature dependence on fuel cell performance.-Figure 1 shows the current density-voltage curves for a PBI-based cell at temperatures of $125,150,175$, and $200^{\circ} \mathrm{C}$, respectively. The cell voltage can be expressed as

$$
E=E_{\mathrm{i}=0}-i R-b \log i
$$

where $E_{\mathrm{i}=0}$ is the open-circuit potential (OCP), $i R$ is the ohmic loss, and the logarithic term is the kinetic polarization of both electrodes. For high current densities an additional term describing the effect of mass-transport limitations should be included. A regression analysis of the polarization curves at different temperatures based on Eq. 6 showed a specific ohmic resistivity of the system from 0.34 to 0.26 $\Omega \mathrm{cm}^{2}$ in the temperature range from 125 to $200^{\circ} \mathrm{C}$. This corresponds to a proton conductivity of 0.019 to $0.025 \mathrm{~S} / \mathrm{cm}$ if the other ohmic contributions are ignored. When ohmic contributions due to electrodes, current collectors, and connections are taken into account, the obtained conductivity values could be slightly higher.

According to previous conductivity measurements ${ }^{34}$ the membranes with similar doping levels exhibit a conductivity of about 0.02 and $0.04 \mathrm{~S} / \mathrm{cm}$ at 125 and $200^{\circ} \mathrm{C}$, respectively. For these conductivity measurements, the atmosphere was saturated with water vapor at room temperature before heated to the respective measuring temperatures. In the present work, water is formed through the cell 


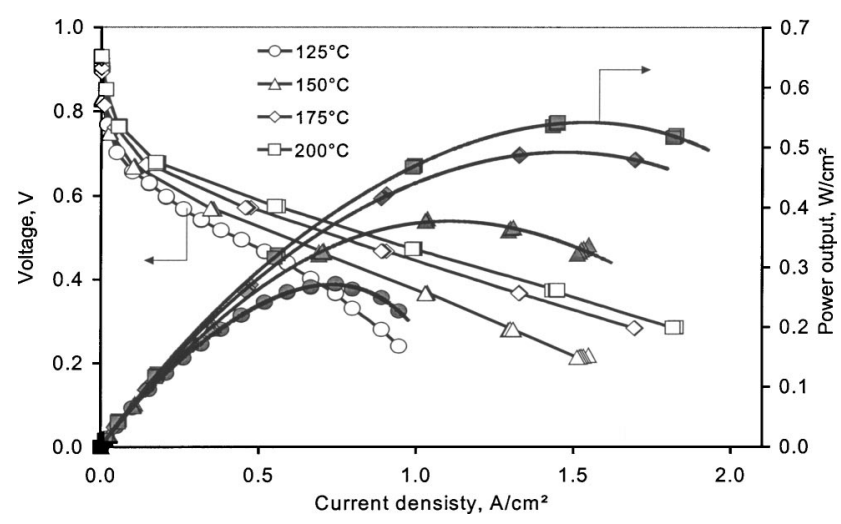

Figure 1. Polarization curves of a PBI-based PEMFCs at different temperatures. The working area of the electrodes was $10 \mathrm{~cm}^{2}$. The PBI membrane was doped with $5.3 \mathrm{~mol} \mathrm{H}_{3} \mathrm{PO}_{4}$ per repeat unit of the polymer. Oxygen and hydrogen were under atmospheric pressure. Hydrogen flow rate $27 \mathrm{~mL}$ $\mathrm{min}^{-1} \mathrm{~cm}^{-2}$. Both anode and cathode were made of carbon-supported platinum catalysts $(20 \% \mathrm{Pt} / \mathrm{C})$ with a platinum loading of $0.5 \mathrm{mg} \mathrm{Pt} / \mathrm{cm}^{2}$. These parameters apply also to the following figures.

reaction and the humidity and therefore the conductivity could be slightly higher. These conductivity values appear to be in good agreement with the present result. These values are relatively low compared with that for Nafion membranes, which is around 0.1 $\mathrm{S} / \mathrm{cm}$ at $80^{\circ} \mathrm{C}$. The thickness of the used membrane is, however, relatively small, about $65 \mu \mathrm{m}$.

The calculated power output as a function of current density is also shown in Fig. 1. At $200^{\circ} \mathrm{C}$ and atmospheric pressure, a power output of around $0.42 \mathrm{~W} \mathrm{~cm}^{-2}$ is obtained at the cell voltage of 0.5 V. At $125^{\circ} \mathrm{C}$, however, this power output is only $0.19 \mathrm{~W} / \mathrm{cm}^{2}$ at the cell voltage of $0.5 \mathrm{~A} / \mathrm{cm}^{2}$.

CO poisoning effect on the fuel cell performance.-Fuel cell performance curves with pure hydrogen and hydrogen containing carbon monoxide are shown in Fig. 2-5 at temperatures of 125, 150, 175 , and $200^{\circ} \mathrm{C}$, respectively. At $125^{\circ} \mathrm{C}, \mathrm{CO}$ contents of $0.1,0.5$, and $1.0 \mathrm{vol} \%$ were tested. The CO contents of $0.5-1.0 \%$ result in significant performance losses already in the low-current-density range, while $0.1 \% \mathrm{CO}$ shows only deviation from the pure hydrogen polarization curve at cell voltages, say, below $0.5 \mathrm{~V}$.

At $150^{\circ} \mathrm{C}$ (see Fig. 3) under the cell voltage of $0.5 \mathrm{~V}$, the current density decreases from $0.58 \mathrm{~A} / \mathrm{cm}^{2}$ for hydrogen to $0.52 \mathrm{~A} / \mathrm{cm}^{2}$ (i.e., decreased by $10 \%$ ) for hydrogen containing $1 \% \mathrm{CO}$, to $0.44 \mathrm{~A} / \mathrm{cm}^{2}$ (decreased by $24 \%$ ) for $3 \% \mathrm{CO}$, to $0.37 \mathrm{~A} / \mathrm{cm}^{2}$ (decreased by $36 \%$ ) for $5 \% \mathrm{CO}$, and to $0.29 \mathrm{~A} / \mathrm{cm}^{2}$ (decreased by $50 \%$ ) for $10 \% \mathrm{CO}$, respectively.

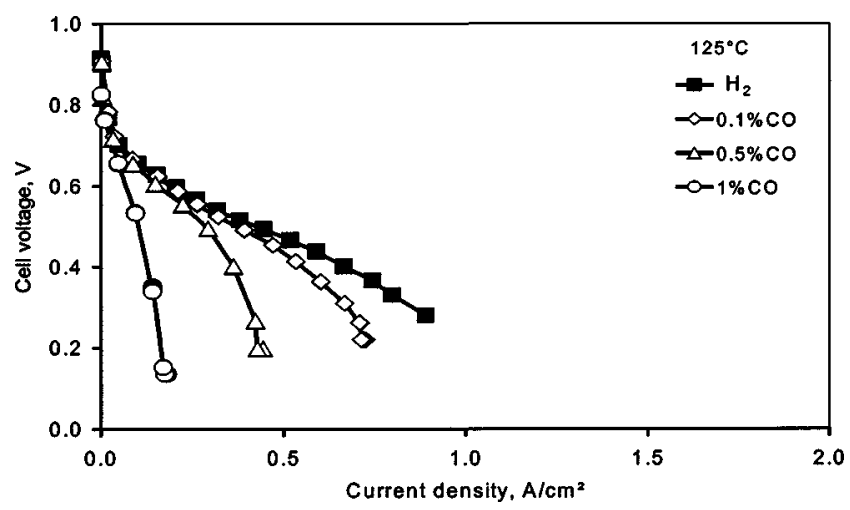

Figure 2. Polarization curves of a PBI-based PEMFC with pure hydrogen and hydrogen containing $\mathrm{CO}$ at $125^{\circ} \mathrm{C}$. The $\mathrm{CO}$ concentrations are indicated in the figure.

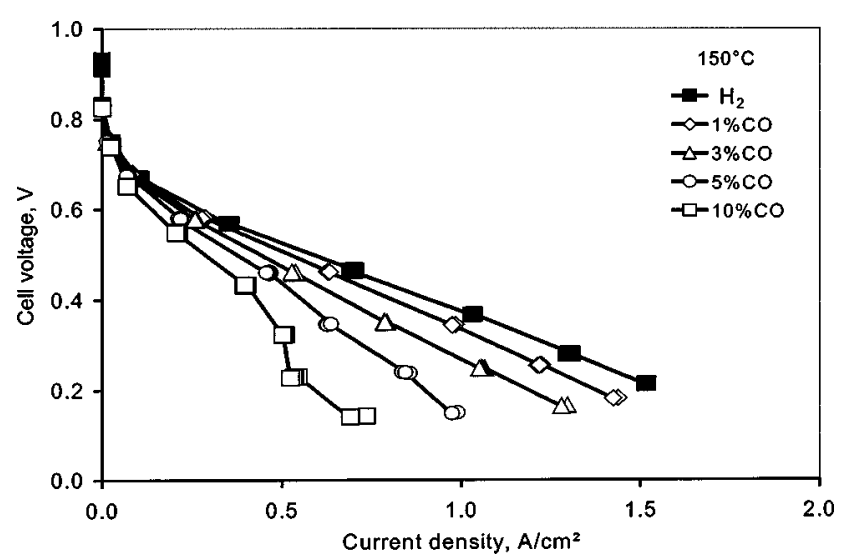

Figure 3. Polarization curves of a PBI-based PEMFC with pure hydrogen and hydrogen containing $\mathrm{CO}$ at $150^{\circ} \mathrm{C}$. The $\mathrm{CO}$ concentrations are indicated in the figure.

At $175^{\circ} \mathrm{C}$ (see Fig. 4), however, $1 \% \mathrm{CO}$ in hydrogen results in a decrease of $1.3 \%$ in current density at the cell voltage of $0.5 \mathrm{~V}, 5 \%$ CO of $11 \%, 10 \% \mathrm{CO}$ of $19 \%$, and $13 \%$ CO of $37 \%$, respectively. At $200^{\circ} \mathrm{C}$ (Fig. 5), $3 \% \mathrm{CO}$ in hydrogen results in no significant performance loss at current densities up to $1.0 \mathrm{~A} / \mathrm{cm}^{2}$ or cell voltage above $0.5 \mathrm{~V}$ at $200^{\circ} \mathrm{C}$. Significant performance losses were observed at CO contents of $10-16 \%$ at cell voltages below $0.7 \mathrm{~V}$.

At high $\mathrm{CO}$ contents, for example, $16 \% \mathrm{CO}$ at $200^{\circ} \mathrm{C}, 13 \% \mathrm{CO}$ at $175^{\circ} \mathrm{C}$, and $10 \% \mathrm{CO}$ at $150^{\circ} \mathrm{C}$, a $\mathrm{Z}$ form of polarization curves was observed, similar to those at $80^{\circ} \mathrm{C}$ with $\mathrm{CO}$ contents higher than 100 ppm. ${ }^{10,17,22}$ As proposed by Bellows et al., ${ }^{25}$ these three regions of the polarization curves can be interpreted using a combination of hydrogen activation (Reaction 1 and 2), adsorbed CO coverage (Reaction 3), and $\mathrm{CO}$ oxidation (Reaction 5). At low current densities, there are enough $\mathrm{CO}$-free $\mathrm{Pt}$ sites to support $\mathrm{H}_{2}$ electro-oxidation with no significant $\mathrm{CO}$ poisoning effect. As current density increases, the hydrogen oxidation is limited by the available Pt sites due to the $\mathrm{CO}$ adsorption. As a result, polarization curves exhibit a Tafel slope much higher than that for the activation hydrogen oxidation. At even higher current densities, the anode potential is high enough to promote a simultaneous oxidation of the adsorbed $\mathrm{CO}$ and an almost constant $\mathrm{CO}$ poisoning overpotential is observed.

Voltage loss due to the $\mathrm{CO}$ poisoning.-The $\mathrm{CO}$ poisoning effect can be better estimated by plotting the power output as a function of the current density. This is shown in Fig. 6, where for the purpose of clarity only a few measurements are presented.

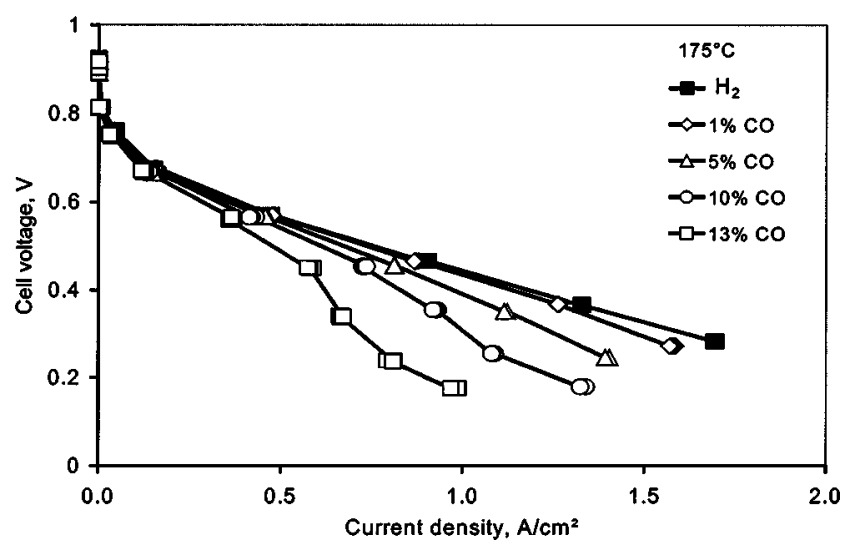

Figure 4. Polarization curves of a PBI-based PEMFC with pure hydrogen and hydrogen containing $\mathrm{CO}$ at $175^{\circ} \mathrm{C}$. The $\mathrm{CO}$ concentrations are indicated in the figure. 


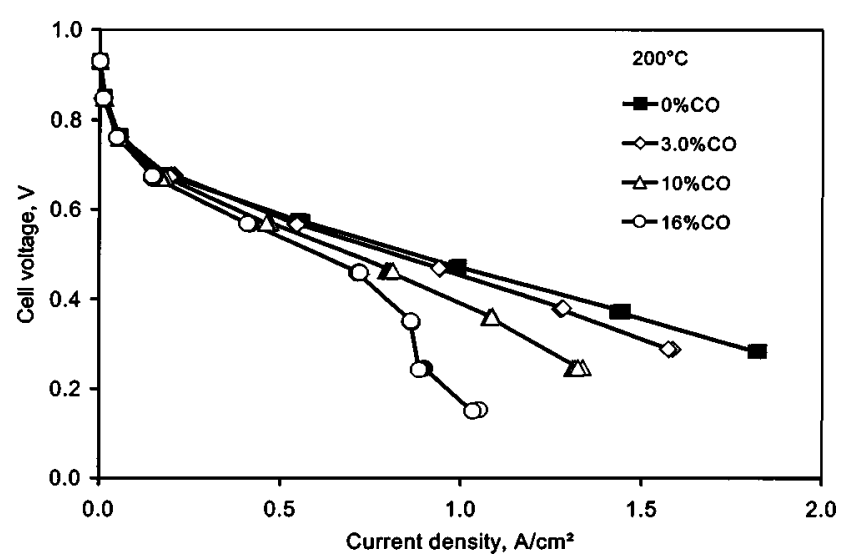

Figure 5. Polarization curves of a PBI-based PEMFC with pure hydrogen and hydrogen containing $\mathrm{CO}$ at $200^{\circ} \mathrm{C}$. The $\mathrm{CO}$ concentrations are indicated in the figure.

Another way to compare the $\mathrm{CO}$ poisoning is to plot the cell voltage loss, i.e., the voltage of CO-free hydrogen minus voltage of $\mathrm{CO}$-containing hydrogen, as a function of current density. As shown in Fig. 7, the cell voltage loss is apparently a function of the CO content, anode catalyst, temperature, and current density.

By defining the $\mathrm{CO}$ tolerance, arbitrarily, however, as less than $10 \mathrm{mV}, 1 \% \mathrm{CO}$ and $3 \% \mathrm{CO}$ in hydrogen can be tolerated at $200^{\circ} \mathrm{C}$ at current densities up to 1.3 and $0.8 \mathrm{~A} / \mathrm{cm}^{2}$, respectively. At 175 and $150^{\circ} \mathrm{C}$, the tolerance of $1.0 \% \mathrm{CO}$ was maintained at current densities up to 1.2 and $0.3 \mathrm{~A} / \mathrm{cm}^{2}$, respectively. At $125^{\circ} \mathrm{C}, 0.1 \% \mathrm{CO}$ in hydrogen can only be tolerated at current densities lower than $0.3 \mathrm{~A} / \mathrm{cm}^{2}$. As a comparison, data for $0.0025 \% \mathrm{CO}(25 \mathrm{ppm})$ in hydrogen at $80^{\circ} \mathrm{C}$ were taken from Ref. 17 , where the $\mathrm{CO}$ can be tolerated at current densities up to $0.2 \mathrm{~A} / \mathrm{cm}^{2}$.

For an approximate estimation, as seen from Fig. 7, the voltage loss of $0.0025 \% \mathrm{CO}$ at $80^{\circ} \mathrm{C}$ is located between the lines for 0.1 and $0.5 \% \mathrm{CO}$ at $125^{\circ} \mathrm{C}$ or between the lines for 1 and $3 \% \mathrm{CO}$ at $150{ }^{\circ} \mathrm{C}$, while the poisoning effects of $3 \% \mathrm{CO}$ at 175 and $200^{\circ} \mathrm{C}$ are much smaller.

The relative activity of anode catalysts for hydrogen oxidation.-To characterize the $\mathrm{CO}$ poisoning effect, the surface coverage of platinum catalysts by $\mathrm{CO}\left(\theta_{\mathrm{CO}}\right)$ has been determined by a number of workers, as summarized by Wilkinson et al. ${ }^{1}$ Under equilibrium conditions, the obtained $\theta_{\mathrm{CO}}$ values varied in a wide range from $9 \%$ for $1 \% \mathrm{CO}$ in $100 \% \mathrm{H}_{3} \mathrm{PO}_{4}$ at $190^{\circ} \mathrm{C}$ to nearly $100 \%$ for $10-100$ ppm $\mathrm{CO}$ in $1 \mathrm{M} \mathrm{HClO}_{4}$ at room temperature.

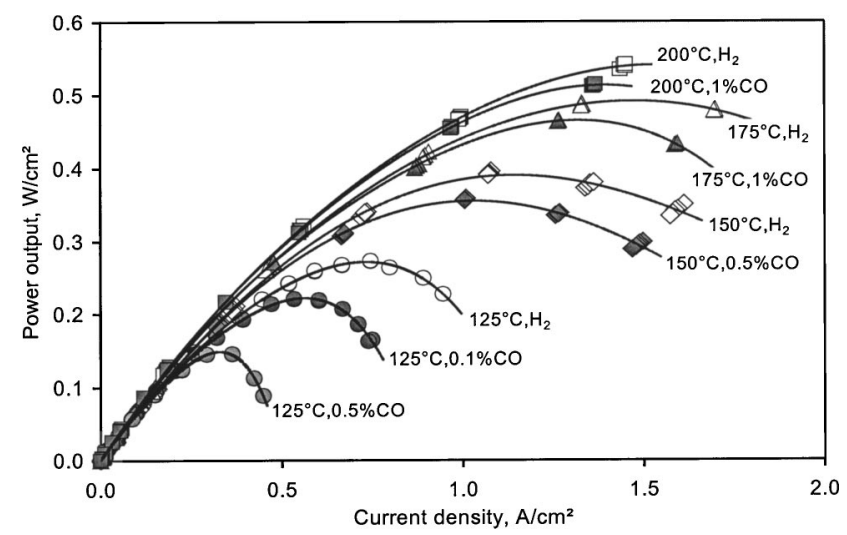

Figure 6. Power output of a PBI-based PEMFC with pure hydrogen and hydrogen containing $\mathrm{CO}$. Temperatures and $\mathrm{CO}$ contents are indicated in the figure.

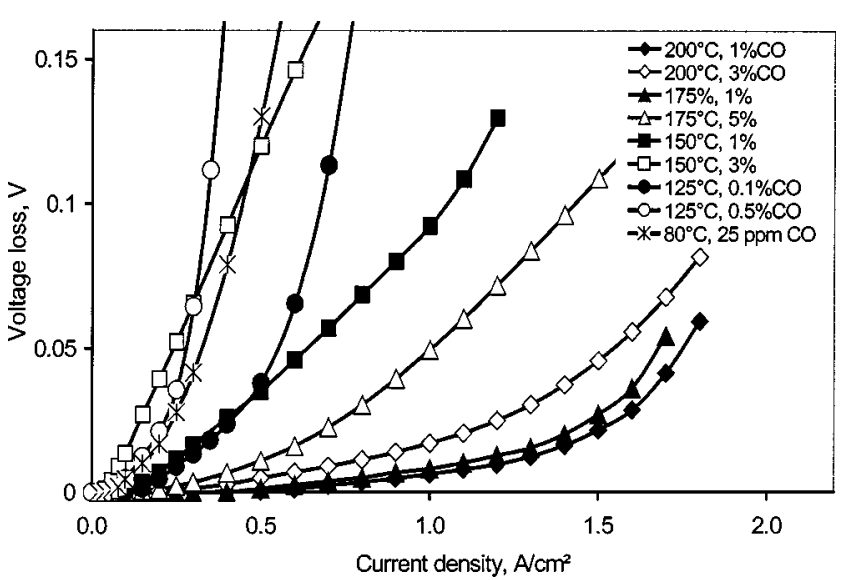

Figure 7. Voltage loss as a function of current density at different temperatures and different $\mathrm{CO}$ concentrations. Data for $25 \mathrm{ppm} \mathrm{CO}$ at $80^{\circ} \mathrm{C}$ were taken from Ref. 17.

Electrochemical stripping voltammetry and polarization measurements are the two main methods for estimation of the $\mathrm{CO}$ surface coverage. Kinetically the measured current of the hydrogen oxidation in either presence or absence of carbon monoxide is directly related to the fraction of unblocked sites, i.e., sites either occupied by $\mathrm{H}$ or available to hydrogen adsorption, $\theta_{\text {unblocked }}$. When the $\mathrm{CO}$ coverage was calculated from the measured current, it was assumed that $\theta_{\mathrm{CO}}$ and $\theta_{\text {unblocked }}$ are simply additive, i.e., $\theta_{\mathrm{CO}}+\theta_{\text {unblocked }}=1$. This is, however, not quite true because of the presence of other possible adsorbed species on the platinum surface.

As seen from Reaction 4, the adsorption of the dissociated water $(-\mathrm{OH})$ occurs. Second, there will always be a number of uncovered surface sites, which are changing according to the adsorption equilibrium. Third, the possible mechanism (Reaction 3) of the $\mathrm{CO}$ adsorption by attacking the free platinum surface sites may not involve the reduction of the hydrogen coverage. Fourth, in the case of aciddoped PBI membranes, the adsorption of the acidic anion $\left(\mathrm{H}_{2} \mathrm{PO}_{4}^{-}\right)$ is significant, which is well known from the research with phosphoric acid as electrolyte. ${ }^{35}$ As reported, the adsorption of $\mathrm{H}_{2} \mathrm{PO}_{4}^{-}$ may account for up to $4 \%$ of the surface coverage in dilute phosphoric acid at room temperature for an adsorption potential of $0.1 \mathrm{~V}$ (vs. RHE). This value would be appreciably high at higher concentrations of phosphoric acid, because the mole ratio of acid to water would be shifted to a large excess of $\mathrm{H}_{2} \mathrm{PO}_{4}^{-}$anions.

In other words, the additivity of the surface coverage of these adsorbed species should include at least the following terms

$$
\theta_{\mathrm{CO}}+\theta_{\mathrm{H}_{2}}+\theta_{\mathrm{H}_{2} \mathrm{O}}+\theta_{\mathrm{H}_{2} \mathrm{PO}_{4}^{-}}+\theta_{\text {unblocked }}=1
$$

where $\theta$ denotes the fraction of surface sites covered by the species indicated, while $\theta_{\text {unblocked }}$ is the fraction of the free surface sites available for any of these absorbate species. The active surface sites available for the hydrogen oxidation, as seen from the previous expression, should include the unblocked sites $\left(\theta_{\text {unblocked }}\right)$ and sites already occupied by hydrogen $\left(\theta_{\mathrm{H}_{2}}\right)$.

Vogel et al. ${ }^{26}$ derived the following expression for calculation of the $\theta_{\mathrm{CO}}$ from the measured anodic currents

$$
i_{\left(\mathrm{CO}+\mathrm{H}_{2}\right)} / i_{\mathrm{H}_{2}}=\left(1-\theta_{\mathrm{CO}}\right)^{2}
$$

where $i_{\mathrm{H}_{2}}$ and $i_{\mathrm{CO}+\mathrm{H}_{2}}$ are the anodic currents due to oxidation of hydrogen and a hydrogen-carbon monoxide mixture, respectively, at a certain overpotential. This equation implies that only adjacent free Pt sites are active for the hydrogen oxidation. It seems that this equation was justified for both planar electrodes and gas diffusion electrodes in the phosphoric acid electrolyte as the observed current- 


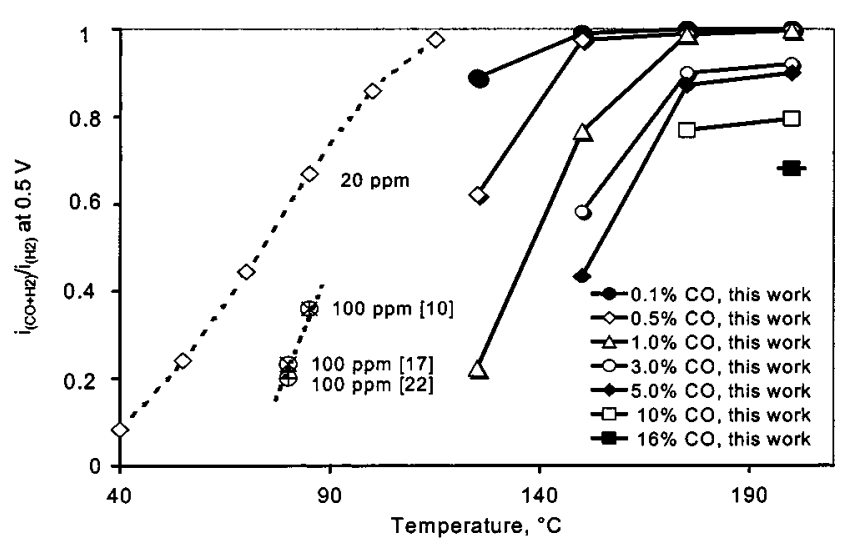

Figure 8. The calculated relative activity of the catalyst for hydrogen oxidation as a function of temperature at different $\mathrm{CO}$ concentrations.

potential curves were linear and the ratio of $i_{\mathrm{CO}+\mathrm{H}_{2}} / i_{\mathrm{H}_{2}}$ did not change at low polarization. Under conditions more appropriate to the operation of PEMFCs, however, Thompsett and Cooper ${ }^{36}$ and Igarashi $e t$ al. $^{4}$ suggested that the current ratio is directly proportional to $\left(1-\theta_{\mathrm{CO}}\right)$

$$
i_{\left(\mathrm{CO}+\mathrm{H}_{2}\right)} / i_{\mathrm{H}_{2}}=1-\theta_{\mathrm{CO}}
$$

The measured current ratio $\left[i_{\left(\mathrm{CO}+\mathrm{H}_{2}\right)} / i_{\mathrm{H}_{2}}\right]$ indicates the decrease in the hydrogen electro-oxidation activity. As Thompsett and Cooper ${ }^{36}$ proposed, the most appropriate measure for the $\mathrm{CO}$ poisoning should be the decrease in fraction of active catalyst surface sites available for the hydrogen oxidation under equilibrium conditions. This measure can be further defined as the ratio of the active surface site number for the $\mathrm{H}_{2}$ oxidation in the presence of $\mathrm{CO}$ to the total surface site number available for the $\mathrm{H}_{2}$ oxidation in the absence of $\mathrm{CO}$, i.e., the simple ratio of poisoned $\mathrm{H}_{2}$ oxidation current to the pure $\mathrm{H}_{2}$ oxidation current, $i_{\mathrm{CO}+\mathrm{H}_{2}} / i_{\mathrm{H}_{2}}$. The physical meaning of this current ratio is the relative activity of the catalysts for hydrogen oxidation at the presence of $\mathrm{CO}$. A value of unity of the ratio $i_{\mathrm{CO}+\mathrm{H}_{2}} / i_{\mathrm{H}_{2}}$ indicates no change in the number of active catalyst surface sites for the hydrogen oxidation even at the presence of $\mathrm{CO}$.

In the present work, a cell voltage of $0.5 \mathrm{~V}$ is chosen for the calculation of $i_{\mathrm{CO}+\mathrm{H}_{2}} / i_{\mathrm{H}_{2}}$ from the polarization curves with pure hydrogen and hydrogen containing $\mathrm{CO}$. Figure 8 shows the calculated $i_{\mathrm{CO}+\mathrm{H}_{2}} / i_{\mathrm{H}_{2}}$ ratio as a function of temperature at different concentrations of CO. As a comparison, data for $20 \mathrm{ppm} \mathrm{CO}$ in the temperature from 40 to $115^{\circ} \mathrm{C}$ from Ref. 10 and for $100 \mathrm{ppm}$ at $80^{\circ} \mathrm{C}$ from Ref. 17 and 22 and $85^{\circ} \mathrm{C}$ from Ref. 10 are also included.

The current ratios should have been obtained at the same anode potential. In the present work, however, they were obtained at the same cell voltage, i.e., when the current density decreased as a result of $\mathrm{CO}$ poisoning, the cathode and ohmic potentials decreased as well. The discussion is therefore only qualitative.

These data are replotted as a function of the $\mathrm{CO}$ concentration $\left(C_{\mathrm{CO}}\right)$ at different temperatures, as shown in Fig. 9. It is seen that the dependence of the $i_{\mathrm{CO}+\mathrm{H}_{2}} / i_{\mathrm{H}_{2}}$ ratio on the $\mathrm{CO}$ concentration obviously is different in the temperature range below 100 and above $120^{\circ} \mathrm{C}$. At 80 and $85^{\circ} \mathrm{C}$ for the data from Ref. 10, 17, and 22 , the $\log \left(i_{\mathrm{CO}+\mathrm{H}_{2}} / i_{\mathrm{H}_{2}}\right) v s . \log \left(C_{\mathrm{CO}}\right.$, in ppm $)$ is linear with a slope from -0.3 to -0.55 , i.e., the logarithm of $i_{\mathrm{CO}+\mathrm{H}_{2}} / i_{\mathrm{H}_{2}}$ ratio is approximately proportional to the logarithm of $\left(C_{\mathrm{CO}}\right)^{-1 / 3--1 / 2}$. In the temperature range from 125 to $200^{\circ} \mathrm{C}$, however, the $i_{\mathrm{CO}+\mathrm{H}_{2}} / i_{\mathrm{H}_{2}}$ ratio is a linear function of the $C_{\mathrm{CO}}$ with a slope of -0.0003 at $200^{\circ} \mathrm{C}$, -0.0002 at $175^{\circ} \mathrm{C},-0.0012$ at $150^{\circ} \mathrm{C}$, and -0.0077 at $125^{\circ} \mathrm{C}$, re-

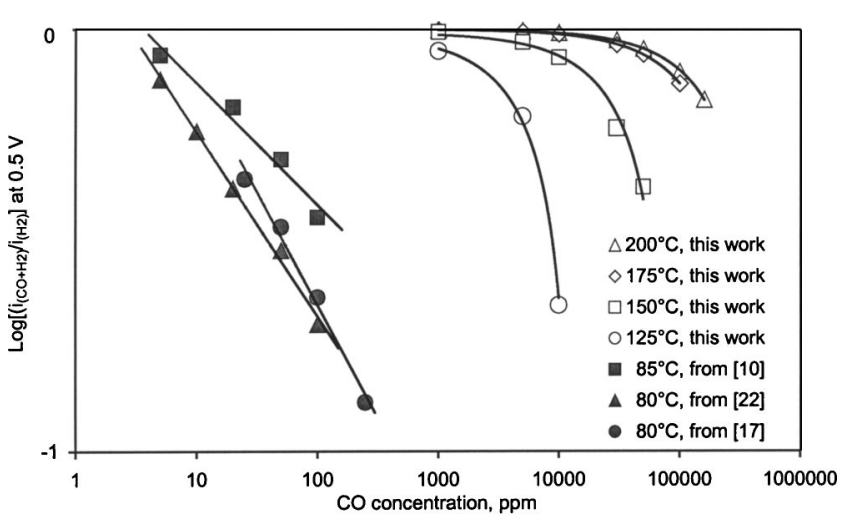

Figure 9. Logarithm of the calculated relative activity vs. logarithm of the $\mathrm{CO}$ concentration at different temperatures.

spectively. The decrease of the slope with increasing temperature apparently indicates the temperature dependence of the $\mathrm{CO}$ poisoning effect.

The $\mathrm{CO}_{2}$ poisoning effect.-Reformed hydrogen is always mixed with a significant amount of carbon dioxide, $\mathrm{CO}_{2}$, due to the carbon atoms of the primary fuel. It is known that the presence of $\mathrm{CO}_{2}$ in the fuel stream does have influence on the PEMFC performance at low temperatures, ${ }^{1,37}$ though the poisoning effect is limited compared to that of $\mathrm{CO}$. While $\mathrm{CO}_{2}$ itself is considered as inert, the poisoning effect is attributable to the formation of $\mathrm{CO}$ by the reverse water-gas shift reaction

$$
\mathrm{H}_{2}+\mathrm{CO}_{2}=\mathrm{H}_{2} \mathrm{O}+\mathrm{CO}
$$

Under operational conditions of the Nafion-based PEMFCs, i.e., the well-humidified fuel feed and low temperatures $\left(c a .80^{\circ} \mathrm{C}\right)$, the formed $\mathrm{CO}$ in a typical gas mixture of $75 \% \mathrm{H}_{2}$ and $25 \% \mathrm{CO}_{2}$ could be in the range $20-50 \mathrm{ppm}$. The formation of $\mathrm{CO}$ is apparently dependent on temperature and the water content in the fuel feed. At $100^{\circ} \mathrm{C}$ with a water content of $15 \%$, for example, it was calculated that the amount of $\mathrm{CO}$ in the gas mixture would increase up to $c a$. $250 \mathrm{ppm} .{ }^{37}$ This presents a significant poisoning effect on the PEMFC performance at $80^{\circ} \mathrm{C}$. The effect may be even more pronounced because the adsorption shifts the equilibrium further toward formation of $\mathrm{CO}$. This poisoning effect was found to be less when $\mathrm{Pt}-\mathrm{Ru}$ alloy catalysts were used as the anode than the pure platinum catalyst. ${ }^{1}$

With PBI-based polymer membrane electrolytes, the fuel cell operates without humidification of reactant gases. The absence of water in the anode feed gas shifts the equilibrium of Reaction 10. As Baschuk and $\mathrm{Li}$ calculated, ${ }^{38}$ as high as $6500 \mathrm{ppm} \mathrm{CO}$ can be formed at zero humidity and $100^{\circ} \mathrm{C}$. By extrapolating these data of Ref. 37 and 38 it seems that $\mathrm{CO}$ formation in the studied temperature range from 125 to $200^{\circ} \mathrm{C}$ would be in a range up to $1 \%$, which is within the tolerance limit.

Figure 10 shows polarization curves obtained at $175^{\circ} \mathrm{C}$ with pure hydrogen and hydrogen containing $25 \% \mathrm{CO}_{2}$. A small performance loss is observed especially at higher current densities. The total gas flow rate for both pure hydrogen and the hydrogen- $\mathrm{CO}_{2}$ mixture was kept constant, about $27 \mathrm{~mL} \mathrm{~min}{ }^{-1} \mathrm{~cm}^{-2}$, corresponding to a maximum theoretical current density of $3.8 \mathrm{~A} / \mathrm{cm}^{2}$ for pure hydrogen and $2.9 \mathrm{~A} / \mathrm{cm}^{2}$ for hydrogen containing $25 \% \mathrm{CO}_{2}$. When the total gas flow rate remains unchanged, the replacement of the $25 \% \mathrm{CO}_{2}$ in hydrogen by nitrogen gives the same performance loss, attributable to a mere dilution effect or, more exact, a lowering of the hydrogen partial pressure (see Fig. 10). 


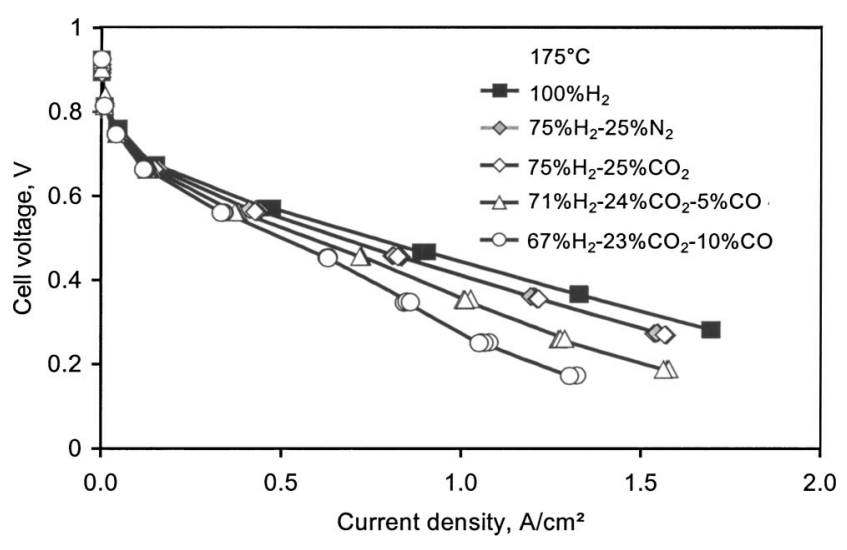

Figure 10. Polarization curves of a PBI-based PEMFC with pure hydrogen and hydrogen containing $\mathrm{CO}_{2}$ and $\mathrm{CO}$ at $175^{\circ} \mathrm{C}$. The total flow rate of

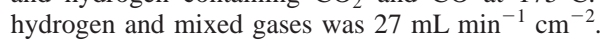

Addition of $\mathrm{CO}$ into the $75 \% \mathrm{H}_{2}$ and $25 \% \mathrm{CO}_{2}$ mixture results in a further decrease in performance, as shown in Fig. 10. Comparison of Fig. 10 and 4 shows no significant change in the $\mathrm{CO}$ poisoning effect when $25 \% \mathrm{CO}_{2}$ is introduced at $175^{\circ} \mathrm{C}$.

The current decay as a function of time.-The $\mathrm{CO}$ poisoning effect is a slow process. Oetjen et al. ${ }^{17}$ reported that a steady-state polarization curve at $80^{\circ} \mathrm{C}$ with $100 \mathrm{ppm} \mathrm{CO}$ was only obtained after $210 \mathrm{~min}$. The current density was $250 \mathrm{~mA} / \mathrm{cm}^{2}$ between the scans. The process was found to be dependent on the $\mathrm{CO}$ concentration and the catalysts. For a PtRu catalyst a steady-state voltage at $400-500 \mathrm{~mA} / \mathrm{cm}^{2}$ was attained after about 100 min. ${ }^{17,24}$ A transient study of the CO poisoning effect by Bauman et al. ${ }^{39}$ showed that the performance loss upon a switch from 0 to $100 \mathrm{ppm} \mathrm{CO}$ at $80^{\circ} \mathrm{C}$ was completed in several minutes. These time frames are apparently dependent on the gas flow rate, setup construction, electrode diffusion layer, catalyst type and loading, CO coverage and adsorption type, temperature, and other parameters.

In Fig. 11 the activity of the applied Pt catalyst is plotted as a function of time at selected temperatures and $\mathrm{CO}$ levels. It is seen that the poisoning rate highly depends on temperature. At $125^{\circ} \mathrm{C}$, a steady-state current density at a cell voltage of $0.5 \mathrm{~V}$ was nearly reached about $1.3 \mathrm{~h}$ after switching the fuel gas from pure hydrogen to $1 \% \mathrm{CO}$ mixture. At 150 and $175^{\circ} \mathrm{C}$, the time was found to be about $50 \mathrm{~min}$ for $1 \% \mathrm{CO}$ and $10 \mathrm{~min}$ for $3 \% \mathrm{CO}$, respectively. At $200^{\circ} \mathrm{C}$, however, the cell performance went to a minimum immedi-

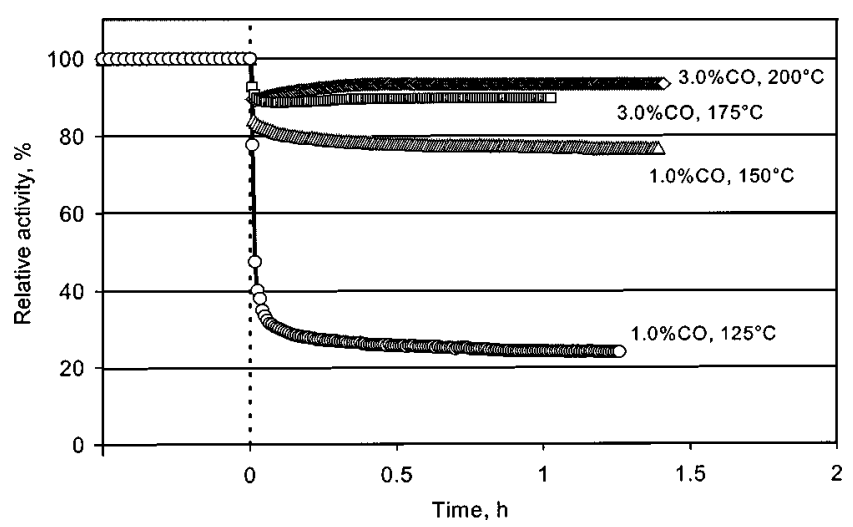

Figure 11. The relative activity of the platinum catalyst as a function of time during the onset of the $\mathrm{CO}$ poisoning at different temperatures. Time $=0$ was the moment when the fuel gas was switched from pure hydrogen to a $\mathrm{H}_{2}$ - $\mathrm{CO}$ mixture. The cell voltage was held at $0.5 \mathrm{~V}$.

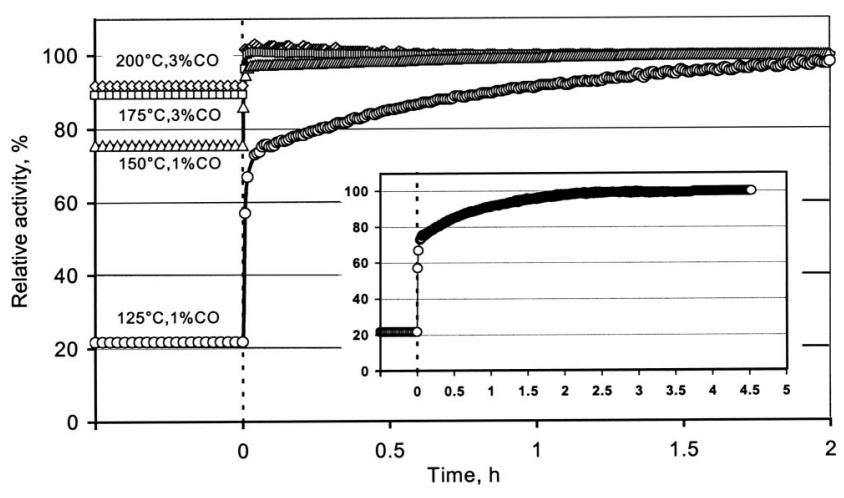

Figure 12. The relative activity of the platinum catalyst as a function of time during the recovery after the $\mathrm{CO}$ poisoning. Time $=0$ was the moment when the fuel gas was switched from a $\mathrm{H}_{2}-\mathrm{CO}$ mixture to pure hydrogen. The cell voltage was held at $0.5 \mathrm{~V}$. The inserted figure is a zoom out of the curve for $125^{\circ} \mathrm{C}$.

ately as the CO-containing fuel was applied and reached a steadystate current density after about half an hour.

It is known that $\mathrm{CO}$ adsorption on a platinum surface is reversible. Figure 12 shows that the cell performance can be restored after poisoning. After a steady-state poisoning was reached, the fuel gas was switched back from the $\mathrm{H}_{2}-\mathrm{CO}$ mixture to pure hydrogen while the cell voltage was maintained at $0.5 \mathrm{~V}$. It is seen from the figure that the previous performance for pure hydrogen can be restored almost immediately from $3 \% \mathrm{CO}$ at 200 and $175^{\circ} \mathrm{C}$. At $150^{\circ} \mathrm{C}$ it took about $1 \mathrm{~h}$ to restore the performance from $1 \% \mathrm{CO}$. At $125^{\circ} \mathrm{C}$, however, the recovery of the poisoning effect is very slow; more than $3 \mathrm{~h}$ were necessary. It seems that the process to restore the initial cell performance after the $\mathrm{CO}$ poisoning is much slower than the poisoning effect, especially at low temperatures, though Divisek et al. $^{24}$ reported the contrary results.

One possible explanation could be that the water content near the anode affects the rate of recovery. This is most likely if the recovery proceeds via water adsorption (see Eq. 4 and 5). Humidified hydrogen, which always is used for Nafion-based cells, is a good water source. In the present work nonhumidified hydrogen was applied and consequently water was only supplied through the backdiffusion via the membrane. The water content is thus expected to be much lower, resulting in a lower rate of $\mathrm{CO}$ oxidation.

\section{Conclusions}

With the acid-doped PBI membranes as electrolyte, the effect of $\mathrm{CO}$ poisoning on carbon-supported platinum catalysts in PEMFCs has been investigated in a temperature range from 125 to $200^{\circ} \mathrm{C}$. By defining the $\mathrm{CO}$ tolerance as a cell voltage loss less than $10 \mathrm{mV}$, the $\mathrm{CO}$ poisoning effect is evaluated. It was found that 1 and $3 \% \mathrm{CO}$ in hydrogen can be tolerated at $200^{\circ} \mathrm{C}$ at current densities up to 1.3 and $0.8 \mathrm{~A} / \mathrm{cm}^{2}$, respectively. At 175 and $150^{\circ} \mathrm{C}$, the tolerance to $1.0 \%$ $\mathrm{CO}$ can be maintained at current densities up to 1.2 and $0.3 \mathrm{~A} / \mathrm{cm}^{2}$, respectively. At $125^{\circ} \mathrm{C}$, however, $0.1 \% \mathrm{CO}$ in hydrogen can only be tolerated at current densities lower than $0.3 \mathrm{~A} / \mathrm{cm}^{2}$. This should be compared with a tolerance to $0.0025 \% \mathrm{CO}(25 \mathrm{ppm})$ at $80^{\circ} \mathrm{C}$ at current densities up to $0.2 \mathrm{~A} / \mathrm{cm}^{2}$. The relative activity of the catalyst for hydrogen oxidation in the presence of $\mathrm{CO}$ was calculated from the measured polarization currents at $0.5 \mathrm{~V}$ as a function of the $\mathrm{CO}$ concentration and temperature. Only a dilution effect was observed for $\mathrm{CO}_{2}$ at a level up to $25 \%$ at $175^{\circ} \mathrm{C}$. The onset and the recovery of the $\mathrm{CO}$ poisoning are strongly dependent on temperature.

\section{Acknowledgment}

This work has received financial support from the European Commission in the 5th Framework Program (contract no. ENK5CT-2000-00323). 
The Technical University of Denmark assisted in meeting the publication costs of this article.

\section{References}

1. D. P. Wilkinson and D. Thompsett, in Proceedings of the Second International Symposium on New Materials for Fuel-Cell and Modern Battery Systems, O. Savadogo and P. R. Roberge, Editors, p. 266, Montréal, Canada (1997).

2. R. M. Q. Mello and E. A. Ticianelli, Electrochim. Acta, 42, 1031 (1997).

3. M. Watanabe and S. Motoo, J. Electroanal. Chem. Interfacial Electrochem., 206, 197 (1986).

4. H. Igarashi, T. Fujino, and M. Watanabe, J. Electroanal. Chem., 391, 119 (1995).

5. T. Springer, T. Zawodzinski, and S. Gottesfeld, in Electrode Materials and Processes for Energy Conversion and Storage IV, J. McBreen, S. Mukerjee, and S. Srinivasan, Editors, PV 97-13, p. 15, The Electrochemical Society Proceedings Series, Pennington, NJ (1997).

6. L. W. Niedrach, D. W. McKee, J. Paynter, and I. F. Danzig, Electrochem. Technol., 5, 318 (1967).

7. D. W. McKee, L. W. Niedrach, J. Paynter, and I. F. Danzig, Electrochem. Technol., 5, 419 (1967).

8. S. Motoo and M. Watanabe, J. Electroanal. Chem. Interfacial Electrochem., 69, 429 (1976).

9. H. A. Gasteiger, N. M. Markovic, and P. N. Ross, Jr., J. Phys. Chem., 99, 8945 (1995).

10. S. J. Lee, S. Mukerjee, E. A. Ticianelli, and J. McBreen, Electrochim. Acta, 44, 3283 (1999)

11. B. N. Grgur, G. Zhuang, N. M. Markovic, and P. N. Ross, Jr., J. Phys. Chem. B, 101, 3910 (1997)

12. B. N. Grgur, N. M. Markovic, and P. N. Ross, Jr., J. Phys. Chem., 102, 2494 (1998).

13. S. Mukerjee, S. J. Lee, E. A. Ticianelli, J. McBreen, B. N. Grgur, N. M. Markovic, P. N. Ross, J. R. Giallombardo, and E. S. De Castro, Electrochem. Solid-State Lett., 2, 12 (1999).

14. K. Y. Chen, P. K. Shen, and A. C. C. Tseung, J. Electrochem. Soc., 142, L185 (1995).

15. K. Y. Chen, Z. Sun, and A. C. C. Tseung, Electrochem. Solid-State Lett., 3, 10 (2000).

16. G. L. Holleck, D. M. Pasquariello, and S. L. Clauson, in Proton Conducting Membrane Fuel Cells II, S. Gottesfeld and T. F. Fuller, Editors, PV 98-27, p. 150, The Electrochemical Society Proceedings Series, Pennington, NJ (1998).

17. H. F. Oetjen, V. M. Schmidt, U. Stimming, and F. Trila, J. Electrochem. Soc., 143, 3838 (1996)
18. M. C. Denis, G. Lalande, D. Guay, J. P. Dodelet, and R. Schulz, J. Appl. Electrochem., 29, 951 (1999).

19. S. D. Lin, T.-C. Hsiao, J.-R. Chang, and A. S. Lin, J. Phys. Chem. B, 103, 97 (1999).

20. T. J. Schmidt, M. Noeske, H. A. Gasteiger, and R. J. Behm, J. Electrochem. Soc., 145, 925 (1998).

21. A. Gasteiger, N. Markovic, P. N. Ross, Jr., and E. J. Cairns, J. Phys. Chem., 98, 617 (1994).

22. S. Gottesfeld and J. Pafford, J. Electrochem. Soc., 135, 2651 (1988).

23. V. M. Schmidt, H. F. Oetjen, and J. Divisek, J. Electrochem. Soc., 144, L237 (1997).

24. J. Divisek, H.-F. Oetjen, V. M. Schmidt, and U. Stimming, Electrochim. Acta, 43, 3811 (1998).

25. R. J. Bellows, E. Marucchi-Soos, and R. P. Reynolds, in Proton Conducting Membrane Fuel Cells II, S. Gottesfeld and T. F. Fuller, Editors, PV 98-27, p. 121, The Electrochemical Society Proceedings Series, Pennington, NJ (1998).

26. W. Vogel, J. Lundquist, P. Ross, and P. Stonehart, Electrochim. Acta, 20, 79 (1975).

27. H. P. Dhar, L. G. Christner, A. K. Kush, and H. C. Maru, J. Electrochem. Soc., 133, 1574 (1986).

28. H. P. Dhar, L. G. Christner, and A. K. Kush, J. Electrochem. Soc., 134, 3021 (1987).

29. G. Xiao, Q. Li, H. A. Hjuler, and N. J. Bjerrum, J. Electrochem. Soc., 142, 2890 (1995).

30. J. S. Wainright, J.-T. Wang, D. Weng, R. F. Savinell, and M. Litt, J. Electrochem. Soc., 142, L121 (1995).

31. Q. Li, H. A. Hjuler, and N. J. Bjerrum, J. Appl. Electrochem., 31, 773 (2001)

32. O. Savadogo and B. Xing, J. New Mater. Electrochem. Syst., 3, 343 (2000).

33. Y. Iwakura, K. Uno, and Y. Imai, J. Polym. Sci., Part A: Gen. Pap., 2, 2605 (1964).

34. R. He, Q. Li, G. Xiao, and N. J. Bjerrum, J. Membr. Sci., Submitted (2002)

35. G. Kohlmayr and P. Stoneheart, Electrochim. Acta, 18, 211 (1973).

36. D. Thompsett and S. J. Cooper, Abstract 607, p. 948, The Electrochemical Society Meeting Abstracts, Vol. 94-2, Miami, FL, Oct 9-14, 1994.

37. F. A. de Bruijn, D. C. Papageorgopoulos, E. F. Sitters, and G. J. M. Janssen, $J$. Power Sources, 110, 117 (2002).

38. J. J. Baschuk and X. Li, Int. J. Energy Res., 25, 695 (2001).

39. J. W. Bauman, T. A. Zawodzinski, Jr., and S. Gottesfeld, in Proton Conducting Membrane Fuel Cells II, S. Gottesfeld and T. F. Fuller, Editors, PV 98-27, p. 136, The Electrochemical Society Proceedings Series, Pennington, NJ (1998). 